\title{
TRADE UNIONS AND THE ENGINEERING INDUSTRY DISPUTE AT BARROW-IN-FURNESS, I $897-98$
}

The lock-out and strike in the British engineering industry, which took place between July 1897 and January 1898, was one of the most bitter and protracted labour disputes of the 1890s. As "the first major national strike or lock-out in British history", ${ }^{1}$ a dispute set against the turbulent background of "new unionism" and socialist influences within the 91,500-strong Amalgamated Society of Engineers, and fought over the issues of working hours, the rights of employers in their own "shops" and the vexed question of the introduction of technical improvements into the industry, the conflict had great political and economic significance. ${ }^{2}$

1 Henry Pelling, A History of British Trade Unionism (London, 1963), p. 112.

2 Unfortunately, the literature on the 1897-98 strike and lock-out is sparse and what little does exist is diffused throughout a wide variety of sources. For the best general survey see H. Clegg, A. Fox and A. F. Thompson, A History of British Trade Unions Since 1889 (Oxford, 1964), I, pp. 138-43, 161-8, but see also E. Halévy, Imperialism and the Rise of Labour (London, 1961 ed.), pp. 250-2, for the contextual political flavour of the dispute. Henry Pelling, op. cit., pp. 112-3, gives a short summary of the affair. Contemporary trade union views of the dispute appear in the ASE Journal and Monthly Record for the period and in George Barnes, The Amalgamated Society of Engineers Jubilee Souvenir 1901 (London, 1901), pp. 104-8. A fuller account, sympathetic to the unions, is provided by J. B. Jefferys, The Story of the Engineers (London, 1945), pp. 136-49. The Webb's History of Trade Unionism (London, 1919 ed.), pp. 484-5, takes a critical look at the unions' tactics. Union leaders' biographies are not very useful sources, e.g., Tom Mann's Memoirs (London, 1967 ed.), pp. 89-90, draws largely on the ASE Jubilee Souvenir 1901. The employers' impressions of the dispute, and the value of its outcome to the industry, appears in the Engineering and Allied Employers' Federation's pamphlet Looking at Industrial Relations (London, 1958). A. Marshall, Principles of Economics (London, 1920 ed.), p. 589, finds that the result of the dispute was of great economic benefit to the engineering industry, while E. H. Phelps Brown, The Growth of British Industrial Relations (London, 1959), pp. 90-8, offers a sympathetic study of craft workers' reactions to technical change. P. W. Kingsford, Engineers, Inventors and Workers (London, 1964), provides a stimulating background history of British engineering. In most of the works cited above there are useful footnotes which serve as guides to related literature. There is very 
The strike also exposed many of the weaknesses which permeated the late-Victorian trade union movement. The unions' trade and organisational sectionalism, their internal political and tactical disagreements and the sharp hostility between skilled workers and labourers were all clearly revealed in the testing experience of the dispute. To an extent, these divisions were obscured at national level by inter-union financial solidarity. But there had been indications of cleavage shortly before the strike began when the national executive committees of the patternmakers', boilermakers' and amalgamated labour unions dissociated their organisations from the other main shipbuilding and engineering unions. However, the full impact of the disuniting tendencies evident on the union side was felt in the separate engineering centres.

Barrow-in-Furness, isolated at the tip of North Lancashire's Furness peninsula, was one such centre. While Barrow did not have as large an engineering industry as districts like Sheffield or the Clyde, much of the town depended upon an important naval shipyard which, in mid-1897, was taken over from the Naval Construction \& Armaments Company by Vickers, Sons \& Co. Ltd. The yard's "achievements in naval new construction had been large and successful. In 1888 it had 872 employees; by 1897 it had 5,500; the docks covered 294 acres and $£ 2 \frac{1}{4}$ millions had been spent on them. In 1896 the yard had completed the first-class cruiser Powerful and the second-class cruisers Juno and Doris, and still had building another first-class cruiser, and four destroyers." 1

The effects of the strike and lock-out on trade unionism were starkly apparent at Barrow because the town had a long-established and well-organised union movement. The main Barrow unions had established their position as a result of the Nine Hours Movement and the local engineering workers' agitation for weekly-paid wages in 1871 . The unions had then launched "a wave of strikes that virtually paralysed the town for many months during 1872 and helped to bring the Barrow Trades Council permanently into existence". ${ }^{2}$ At that time the local unions included the boilermakers, engineers, moulders, blacksmiths, engine drivers, the two carpenters' and joiners' societies, bricklayers, stonemasons and tailors. Trade-union growth continued

little material on the history of the dispute in the local engineering centres, but see Sidney Pollard, A History of Labour in Sheffield (Liverpool, 1959), pp. 232, 239 and 241. In Sheffield, about 1200 men were directly affected by the strike, and a further 600-800 labourers were rendered unemployed.

1 J. D. Scott, Vickers: A History (London, 1962), p. 44.

2 Jack Mowat, "1871 and the forging of union solidarity", in: Barrow Evening Mail, 4 November 1971, p. 8. 
slowly until the 1880s and 1890s. "In 1896 the Barrow Trades Council had 2873 subscribing members belonging to 21 affiliated societies, as compared with about 600 members in 1883."1 By 1897 the 52-delegate Trades Council represented about 3000 workers through 23 affiliated unions. The Council was at the head of the Barrow trade union movement and, in 1898, "the collective experiences of its members were slowly changing it from an organisation concerned solely with the protection of 'craft basis' and union business to that of a local parliament of workers fully alive to the changing political currents of the time". ${ }^{2}$

A major harbinger of this change had been the emergence of general labour unions at Barrow. The Barrow labourers shared in the stimulus provided for general unions by the "new unionism" of the late-1880s. A short-lived branch of the National Union of Dock Labourers was formed in 1890, a branch of the National Amalgamated Union of Labour in 1891 (the union had two Barrow branches by 1897), and the National Union of Gas Workers and General Labourers had opened a branch by March 1894. Altogether, about 30 per cent of Barrow's labourers were unionised by 1897 and, like their contempories elsewhere, they were concentrated at a single place of employment - in this case, the shipyard. ${ }^{3}$ The NAUL and the NUGW \& GL branches were affiliated to the Trades Council which had fully supported attempts to organise the labourers. In fact, Barrow's first socialist parliamentary candidate, Peter Curran, who contested the 1895 general election for the Independent Labour Party, was an official of the NUGW \& GL. Thus, Barrow had a highly organised trade union movement which itself had a developing degree of political sophistication and unity. The engineering dispute was to cause havoc with these labour relationships.

\section{I}

The immediate cause of the 1897-98 lock-out and strike stemmed from the escalation of a dispute between the London engineering employers and the metropolitan workers' Eight Hour Day Committee. The London men struck work on 3 July 1897 to press their demand for

1 J. D. Marshall, Furness and the Industrial Revolution (Barrow-in-Furness, 1958), p. 400.

${ }^{2}$ Jack Mowat and Albert Power, Our Struggle for Socialism in Barrow: A short history of the Barrow Labour Party (Barrow-in-Furness, 1950), p. 14.

3 Barrow appears typical of the trends in general labour unionism noted by $\mathbf{E}$. J. Hobsbawm, "General Labour Unions in Britain, 1889-1914", in Labouring Men (London, 1968). 
a 48-hours working week. The engineering employers retaliated by announcing a nationwide lock-out of 25 per cent of their engineering workers, and the unions hit back by withdrawing the remaining 75 per cent of their members from the affected firms. Thirty-five thousand workers were directly affected by the stoppage, including twenty-seven thousand engineers. Although the length of the working day was apparently at the centre of the dispute, the key issue, for many in the industry, was the basis on which engineering work practices would develop in the future. Under the pressures of foreign competition principally from the German and the United States' engineering industries - the British industry was being forced to adopt new methods of production.

New techniques, however, disrupted traditional craft customs and practices as "pattern making, foundry work, blacksmiths' work, and boilermaking all saw the appearance of minor labour-saving devices; but the most fundamental and rapid changes were taking place in the machine shop, which, with its fitters and turners, was the heart of the Engineers' empire. About 1890 came the capstan and turret lathe, the vertical, horizontal, and later the universal milling machine, the external and surface grinder, the vertical borer, and the radial drill. Work on these specialist machines did not require the all-round competence of the craftsman, and many of the men put on to them, at wage rates below craft standards, had neither served an apprenticeship nor picked up a broad experience on the shop floor. The fitters and turners were soon faced with a growing threat from the 'dilution' of their skills, which was sharply underlined when unemployment rose from 2 per cent in 1890 to 11 per cent in 1893. Moreover, as improvization gave way to planning, works engineers, planners, inspectors, rate-fixers, and progress men appeared. The latitude once allowed to the good craftsman was reduced by detailed specification, close inspection, and tighter supervision, while speeding-up was encouraged by the growth of payment by results." 1

The consequences of these new developments produced a host of disputes between 1890 and 1897 concerning piecework, overtime, apprenticeship rules and the terms on which employers could introduce new machines into their shops. The shipyard unions at Barrow faced lock-out threats in September 1896 and again in March 1897. The frequency of brinkmanship in the Barrow yard was also connected with the affiliation of the local employers' association to the new, national Employers' Federation of Engineering Associations in June 1896. The EFEA, with its object "to protect and defend the interests

1 Clegg, Fox and Thompson, op. cit., I, pp. 138-9. 
of employers against combinations of workmen", had introduced a new element into industrial relations: "Every small dispute in which a federated firm was involved was referred to the central body and the threat of a lock-out became, in the words of one member, a 'hardy semi-annual event'." 1 The situation in the engineering industry had clearly reached a state of high tension by 1897 and required only the provocation of the eight hours' demand to produce a crisis of major proportions.

At Barrow, as elsewhere, the ASE, the Steam Engine Makers' Society, the United Machine Workers' Association and the National United Engineers' Society declared a strike in the shipyard from 13 July 1897 - the date set by the employers for the enforcement of their lock-out notices. The ASE Barrow district committee had been committed, by a resolution passed at a members' meeting, to hold mass meetings to determine dispute policy. On 15 July the first of these meetings elected 20 members to a Lock-Out Committee established independently of the official district committee. The LOC met every day to conduct strike business, distribute union benefit, raise funds, book meeting rooms, keep track of work contracted out from "blacked" shops, arrange picketing and control the movement of engineers in and out of Barrow. The ASE district committee set up a sub-committee to liaise with the LOC. Two smaller unions - the SEM and the UMWA were also represented on the LOC. By 20 July there were 1200 men out of work. These included 650 of the one thousand Barrow ASE members, 450 other trades (mainly SEM) and one hundred labourers. A number of the non-union men left work in sympathy with the engineers but many others, ignoring union picket lines, remained at their machines.

Although the LOC quickly sought to consolidate its position, mainly by holding a series of public meetings in Barrow's main squares, the choice of speakers to address the meetings opened political divisions within the ASE. At the end of July the LOC split by eight votes to four against inviting a speaker on the eight hour day, and instead, arranged a meeting on the broad state of the dispute. The LOC had earlier asked the ASE district committee to invite John Burns MP to come to a meeting in Barrow. The union's national council, however, had offered the socialist militant Tom Mann as a speaker. The offer was rejected when the Barrow district committee, after a tied vote of three to three, decided on the casting vote of their president to insist on the more respectable Burns as "he would have more weight with the general public and also would be more acceptable to our

1 J. B. Jefferys, op. cit., p. 144. 
members". ${ }^{1}$ This was a significant comment on Mann's local standing because he had already addressed a large ILP meeting at Barrow on 3 July. The ASE leadership relented and, in August, Burns came to Barrow.

More serious than the Burns-Mann controversy were the sectional divisions which soon began to impede the unity of the "allied" trades. The LOC and the ASE district committee clashed over their respective powers and authority on 26 July when the latter demanded that the LOC pay full dispute benefit to non-unionists as well as to union members. The LOC also ran foul of several ASE branch committees. One branch complained in early August that it had not been consulted when one of its members was withdrawn from the shipyard by the LOC. In defence of their autonomy the branches forced a vote in the LOC on 16 August which, by 12 votes to eight, allowed the branches to decide whether a member might leave the town during the dispute. A deeper schism occurred at about this time when the SEM, anxious to retain its freedom of action as well as tight control over the allocation of dispute benefit to its members, left the ASE-dominated LOC. The traditional prerogatives enjoyed by the seperate union organisations were being reasserted under the pressure of the dispute.

\section{II}

Quite the worst direct effect of the strike was a sudden deterioration in the relationship between the allied trades and the labourers' unions. Tensions already existed as a result of the ramifications of the "machine question" in the engineering industry. From 1894 there had been a "vigorous campaign on the part of the [ASE] against the use of unskilled men on machines" at Barrow. 2 So far as the NAUL was concerned the manning of machines was only one part of a history of second-class treatment meeted out to labourers by the skilled workers' unions. Three days before the dispute began the executive of the NAUL issued a branch circular on the union's position:

"As neither our members nor the union have been consulted in any way on the question of the eight hour day in the engineering trade, and seeing that the engineers refused to allow the labourers to act with them in the last [wage] advance, and seeing also that our members are chiefly employed in districts outside of London, and will not, therefore, receive any benefit whatever the ultimate

1 Amalgamated Society of Engineers, Minutes of the Local District Committee, 28 July 1897.

2 J. D. Marshall, op. cit., p. 400. 
settlement is, the Executive Council advises our members to remain at work - A. T. DIPPER, general secretary."1

To make matters more difficult the NAUL executive's advice could not be fully taken up at centres like Barrow where Vickers laid off their labourers as soon as the dispute started to cripple production. The distressing circumstances in which the rapidly increasing numbers of unemployed labourers found themselves led to the creation of their own relief committee on 30 July. Their bitterness actually crystalised around the provision of relief and this, in turn, provoked splits in the Barrow Trades Council. The Council had been asked, by the LOC, to organise financial assistance. During the second week in August the Trades Council's executive committee published a statement "recognising the importance of the struggle the Amalgamated Society of Engineers and Kindred Trades have entered upon, and its value to the whole of the workers of this country". ${ }^{2}$ The Council opened a fund for the relief of distress caused by the conflict and asked the labourers' relief committee to join forces. The labourers, for their part, refused to unite with the Trades Council fund and went on to allege, incorrectly, that the Council would help only union members whereas the labourers' committee did not discriminate.

Charge and counter-charge publicly passed between the labourers and the Council for two months. The labourers claimed, this time accurately, that a donation of five guineas made by a town councillor to the labourers' committee had been sent by mistake to the Trades Council. The Council was called upon to release the money. John Martin, the chairman of the labourers' committee, moved a motion to that effect at the Trades Council meeting in August but he was promptly ruled out of order by Archibald Barrie, the Council's president and prominent ASE member. As an additional complication the treasurer of the Trades Council fund, a socialist named Robert Knightly, was a member of the Barrow NAUL No. 1 branch. Heaping fuel on the fire, Knightly criticised the labourers' committee for paying themselves a 28 shillings salary out of their relief collections. The charge later turned out to be true but not before it had been denied by John McGuire, the treasurer of the labourers' committee, and whose own NAUL No. 47 branch "severely condemned" Knightly for "opposing and attacking the authorised Labourers' Relief Committee".3 Knightly's branch spoke up in his defence and, in a letter to the Barrow Herald of 31

1 Cited in the Barrow Herald, 10 July 1897, p. 8.

2 Ibid., 14 August 1897, p. 8.

- Barrow News, 21 August 1897, p. 8. 
August, said his charges were "justified" and "condemned" No. 47 branch.

The labourers' own internal row was a side show compared with their main fight with the Trades Council. A Council sub-committee toured all affiliated organisations in late August to secure support for their fund. They were "staggered" when "on visiting the Labourers' Committee, the sub-committee found the Chairman and Officers absent, but a note had been left which read as follows: 'Labourers' Committee, August 20th. Proposed that we do not receive deputation from Trades Council. Carried unanimously' - J. MARTIN, chairman." A few days later the Council's delegation did meet the labourers but were told that the labourers' committee would "steer clear" of the Council. ${ }^{1}$ Sam Hereford, the secretary of the labourers' committee, emphasised the labourers' stand by publicly stating that they would have nothing to do with the Trades Council fund while its sponsors sent money "to fitters and machine-men, at present being assisted by the ASE".

The full measure of the labourers/Trades-Council split is best grasped by running ahead of the narrative at this point. At a Trades Council meeting on 9 September there were attempts, led by the Liberal ex-secretary of the Council and supported by a bloc of craft delegates, to suspend the labourers' delegates for refusing to co-operate with the Council. One delegate expressed the sentiments of many of his colleagues when he said 'it would be better if the 'poor labourers' would practice a bit of economy while they were able, and stop a few of their pints". ${ }^{3}$ The meeting, however, deferred their decision in order to allow the NUGW \& GL to consider its position. The Barrow branch of the NUGW \& GL had generally supported the two NAUL branches and when the Trades Council's officers met the NUGW \& GL, on 21 September, they were greeted with a storm of abuse. The Council was accused of dishonesty in withholding money intended for the labourers' committee. Discord between the engineers and the labourers was apparent in the labourers' complaints that they would receive only two shillings or two-shillings-and-ninepence unemployment relief a week, under the Trades Council scheme, while skilled men received seven shillings. The NUGW \& GL decided to boycott the Council's fund.

The following month a stormy Trades Council meeting heard a report from the officers on their meeting with the NUGW \& GL.

1 Herald, 28 August 1897, p. 6.

${ }^{2}$ News, 24 August 1897, p. 3.

3 Ibid., 11 September 1897, p. 8. 
"During the time that the delegates were giving their report, the labourers' representatives kept up a series of interruptions, Mr. Martin having to be reprimanded. [A delegate] was called upon to withdraw the term 'blackleg' that he had used in answering a question of $\mathrm{Mr}$. McGuire."1 In the second half of November general antagonism was intensified. The ASE discovered that plumbers' labourers, in the shipyard, were doing an ASE job - making steam joints - even though the plumbers had refused to do the work. When the Trades Council met again, at the beginning of December, the sitting representatives of the labourers' unions were finally expelled and the NUGW \& GL and the NAUL were invited to appoint new delegates. The NUGW \& GL did send two new representatives, in January 1898, but the Council objected to one of these whom, it was alleged, had an "uncooperative attitude". At the same meeting, the boilermakers condemned labourers at Birkenhead for doing drillers' work during the dispute. The two sides had moved so far apart that the NAUL now completely ignored the Trades Council and, in March 1898, the NUGW \& GL formally disaffiliated.

\section{III}

The allied trades, despite their steadily deteriorating relationship with the labourers and their own internal frictions, had some good reasons for satisfaction by the end of August 1897. Almost two hundred firms had conceded the eight hours day in London. It was not until the following months that the employers' federation effectively organised the London firms and managed to whip provincial recalcitrants into line by means of a trade boycott. At Barrow, the shipyard was in difficulties. The journal Marine Engineering reported in August that "the strike or lock-out is having a very serious effect on the work in hand, although some good work is being done by means of the [150] apprentices".

But even among the apprentices there was growing support for the unions. This support appeared to be due more to the enthusiasm of the apprentices than to the inspiration - or, rather, lack of it - provided by the conservative union leaderships. A number of apprentices were sacked for refusing to do ASE work and others stopped working as they completed their apprenticeships. In October, the Barrow News reported that the shipyard apprentices had threatened to strike against the employment of non-union labour and the management had warned that any strikers would be sacked. On 26 October "a young man

1 Ibid., 2 November 1897, p. 3. 
named D. Allen came before the Lock-Out Committee and made a statement to the following effect. The apprentices had a meeting amongst themselves and decided to ask certain Blacklegs, who were working in the Engine Shop, to leave the Shop, or they would carry them out. He stated that they had been successful in getting the men to leave their work." 1 Twelve days later several young men, who had been put on to ASE machines at the yard, walked out in solidarity with the engineers and in the face of an employer's warning "that if they left their work they would never be allowed to start at the Shop again, nor yet in any of the Federated Shops". ${ }^{2}$ The apprentices had taken a courageous step. At the same time, the attitude of the local union leaders towards the apprentices was, to say the least, cool; youths were supposed to act like full trade unionists only after they had "served their time".

Support for the allied trades was also forthcoming, by September, from groups of workers not directly involved in the engineering dispute. Workers at the Barrow Iron Works and iron ore miners at nearby Dalton-in-Furness held weekly collections in aid of the LOC. The Barrow, Dalton and Cleator Moor Co-operative Societies also donated to the various dispute funds. On the other hand, the allied trades were coming under increasing pressures. A second Barrow firm, Mechan \& Sons, joined the dispute in September. The company had locked-out its Glasgow employees, causing the ASE to declare a strike at the firm's Barrow premises. This new strike placed an additional strain on the unions' precarious finances. By 4 October the funds of the National United Engineers' Society were exhausted and its members became an ASE responsibility. The ASE's own dispute benefit was reduced on 19 October from 15 shillings to 12 shillings a week for a single man; married men continued to receive 15 shillings. Attempts to solicit subscriptions in Lancaster, the nearest large town, appear to have produced the amazingly small sum of nine shillings. In November the ASE district committee tried to raise loans.

The National Free Labour Association's intervention in the dispute brought new problems for the unions. The Association's main object was to provide employers with labour during strikes and lock-outs. ${ }^{3}$ The NFLA is generally considered to have been of little use to the engineering employers because it could not supply enough skilled

\footnotetext{
1 Amalgamated Society of Engineers, Minutes of the Barrow Lock-Out Committee (hereafter ASE/LOC), 26 October 1897.

2 ASE/LOC, 8 November 1897.

3 See J. Saville, "Trade Unions and Free Labour", in: A. Briggs and J. Saville (eds), Essays in Labour History (1960), p. 339, for an evaluation of the usefulness of the NFLA to the engineering employers.
} 
labour to replace the ASE men. This was certainly the case at Barrow where "blacklegs" were sent by a Free Labour Agent at Newcastleupon-Tyne. When the Free Labour men arrived at Barrow railway station a line of union pickets asked them to leave the town. The pickets usually had their way but only at the cost of paying the Free Labour men's return fares. This occurred on at least ten occasions between mid-October 1897 and mid-January 1898. In addition, there were non-union men in Barrow who were given lock-out benefit because they might otherwise "be likely to go and get a job at the Naval Construction Co." 1 The net result was a drain on union funds.

The allied trades' financial needs had the effect of exacerbating many existing tensions within the Barrow trade union movement. The ASE district committee, for example, provoked more sectionalism when, on 20 September, they issued a circular requesting

"the various branch secretaries in Barrow to take a vote of their members as to whether they will consent to a local levy of $6 \mathrm{~d}$ per week, as the lock-out committee are being constantly pressed for assistance from members who are in distressed circumstances and have not the funds to relieve these very necessitous cases."2

When the vote had been taken, by 4 October, the branches were found to have rejected the levy. A grand total of 37 members had voted at the branch meetings. Even if the levy ballot had been restricted to those ASE members still at work there should have been a couple of hundred votes. However, the branch meetings attracted that minority of members interested in branch administration and they appear to have treated the ballot as a way of expressing their independence from the district and lock-out committees. Possibly, the adverse vote was in retalliation to the LOC's victory, on 1 September, when the power to decide whether engineers could leave Barrow during the dispute was wrested from the branches.

If fund-raising was difficult so, too, was the distribution of relief. Early in October the Trades Council, sensitive to the labourers' charges, sought greater control over the relief it was giving to the engineers' LOC. The Council asked the ASE for information about the individuals in receipt of relief but the LOC, sensing an infringement of its integrity and authority by an "outside" organisation, refused to co-operate. Feelings ran high and, on 8 October, there was a drastic move in the

${ }^{1}$ ASE/LOC, 19 October 1897. The shipyard was still popularly known by its old title.

${ }^{2}$ ASE, Minutes of the Local District Committee, 20 September 1897. 
LOC to "withdraw our connection from the local Trades Council". 1 The matter was allowed to drop for the time being, but on 14 October the LOC received another letter from the Trades Council, "the purport of which was that that body decline to assist any case unless the Names and Addresses of applicants are given". The LOC at once sent a sharp reply,

"indicating that this Committee decline to depart from the procedure of the last 13 weeks and if the Executive Committee of the Trades Council are in doubt as to the manner the monies received from that body [are distributed] that our Books are open for the inspection of any deputation whom they may feel disposed to appoint". ${ }^{2}$

The engineers' LOC and the labourers' committee were not the Trades Council's only critics. The SEM, which had set up its own relief committee, attacked the Council's scheme of relief and "the manner in which it was being distributed by them". ${ }^{3}$

The SEM extended its criticism to the Barrow Co-operative Society. Until late October the Society, which had a great many trade unionists among its members, had distributed cash to the different workers' relief funds, but from 1 November food tickets exchangeable for goods at co-operative stores were substituted. The Society discovered that the change had upset the SEM, which complained to the board of management about "the way in which we are giving relief" on 8 November and again on 9 November. ${ }^{4}$ The relief question had already created other problems for the Barrow "co-op". At first the Society's directors had hoped for a large slice of the $£ 3000$ allocated for relief by the Co-operative Wholesale Society. As it happened, Barrow received a mere $£ 25$ from the CWS. The Barrow co-operators angrily protested that "we are very much dissatisfied at the smallness of the amount and considering the members out of work here we are entitled to a much larger sum". ${ }^{5}$ As only another $£ 25$ could be obtained from the Wholesale Society the Barrow board decided to alter their rules to facilitate local donations to relief funds. At this point the Society's

1 ASE/LOC, 8 October 1897.

2 Ibid., 14 October 1897.

3 Barrow Co-operative Society, Minutes of the Board of Management, 8 November 1897 .

4 Ibid., 8 and 9 November 1897. Members of the ASE had been associated with the Barrow Co-operative Society since its establishment in 1860 . The links between the two organisations had weakened over the intervening years, but the Society was still, to some extent, publicly identified with the ASE in 1897. 5 Ibid., Letter from the Barrow Co-operative Society to the CWS, 11 October 1897. 
internal politics intervened and a special members' meeting, on 3 November, called to alter the rules turned into a hotly contested battle. The board recommended that grants, not exceeding two-and-ahalf per cent of the net profits for the appropriate quarter-year, be allowed for any purpose. A minority of members opposed the recommendation on the grounds that it would commit the Society to general support of trade union and political action. An amendment intended to limit grants to "charitable philanthropic objects only" was defeated but a further amendment reduced the size of grants to one per cent of net profits in any quarter. ${ }^{1}$ At the end of November the Society donated $£ 45$ to the LOC.

\section{IV}

The Co-operative Society's donation was particularly welcome to the LOC because the strikers' families were becoming poverty-stricken towards the end of November. The committee noted two poignant, but not unusual, cases of hardship early in December:

"Bro. Edmundson reported that he had a father and mother depending upon him for support and he was only in receipt of $8 /-$ per week. The Committee decided to allow him the sum of $3 /$ - from the emergency fund."2

"Bro. A. Singleton came before the Committee this morning, he being in straightened circumstances having in all 3 children who are lying ill and one dead, he having no means at his disposal to have this one interred. The Committee decided that a grant of $£ 2$ be given to him to assist him through his present difficulty."

The allied trades situation had become desperate by mid-December. There was a deepening poverty among the members which implied a depressing Christmas and New Year. The protracted nature of the dispute was producing a growing frustration within the union ranks. It became normal for a proportion of men to be absent from their spell of picket duty. Having nothing else to offer to rouse the men's flagging morale, the LOC introduced fines for absence from picketing. The fines had little effect, and in mid-January 1898 the fall in the numbers of pickets reporting for duty was still causing concern. By this time there was considerable confusion about the pending settlement with the employers. There had been two abortive sets of national

1 Ibid., 3 November 1897.

2 ASE/LOC, 6 December 1897.

3 Ibid., 8 December 1897. 
negotiations in November and December 1897. Nevertheless, the ASE Executive, alarmed by the startling cost of the dispute, which had risen to between $£ 25,000$ and $£ 30,000$ a week, again met the employers in January 1898. The eight hours' day demand was withdrawn and a clarification of the employers' previous terms was secured. In late January the Executive recommended the acceptance of these terms of settlement to the membership, but not before the Barrow press had twice mistakenly reported that the dispute had ended.

A succession of telegrams passed between the confused Barrow LOC and the ASE Executive in London. On 17 January the LOC telegraphed for "information of our actual position at once. Also state of policy to be pursued. Men restless." The immediate reply from George Barnes, the ASE's general secretary, was " 48 hours withdrawn but men must not start except on old terms". ${ }^{1}$ This was too much for the LOC. The committee split six votes to five against meeting the local employers to discuss a return to work on pre-dispute terms and, instead, decided on 18 January to place the decision in the hands of a mass meeting. The following day the LOC was still in communication with Barnes, who advised the Barrow leaders to "keep the men together in resisting terms". Meanwhile, violence was creeping on to the local scene. Two shipyard workers were assaulted on their way to work. This incident was followed by a large street fight, involving striking engineers and men still employed, which took place outside the LOC's headquarters, the Crow's Nest public house. The allied trades began to return to work on 31 January in accordance with the settlement conditions.

The 1897-98 strike and lock-out was a major defeat for the engineering trade unions. The eight hours day was lost, the employers achieved greater freedom to install new machines and to insist on new work practices. Widespread piecework was enforced and many limitations on the employment of non-union labour were removed. By their intransigence during negotiations the unions did manage to secure the right of collective bargaining on general wage claims and, also, the right of unions to participate in the employers' formal disputes procedures. ${ }^{2}$ But the struggle cost the ASE alone $£ 658,000$.

1 Ibid., 17 January 1898.

2 There were some other developments. The General Federation of Trade Unions (founded 1899) was a product of the impetus given to the idea of forming a federation of trade unions for mutual financial support by the engineers' defeat. There is a hint in Ton Mann's Memoirs that he and Charles Duncan, who was 
When full account is taken of the unions' conduct of the strike at a well-organised centre like Barrow it is not hard to find some contributory causes of the defeat. The entire dispute was characterised, on the union side, by internal ill-will and disunity. If anything was proved it was that the engineering unions could not handle a situation which required a firm united front on their part. Their traditional sectional divisions, forged over years of inter-union disputes in a thoroughly demarcation-ridden industry, presented a formidable barrier to labour unity. It was hardly surprising, therefore, that there should be so much additional resentment against the involvement in the strike of "outside" bodies - i.e. the Lock-Out Committee and the Trades Council which fitted only with difficulty into the established framework of trade unionism. On top of these problems, the unions allowed the dispute to become a focal point for an expression of the backlog of hostility existing between skilled workers and labourers. Even when active solidarity was offered - by the apprentices, for example narrow, parochial conceptions of trade unionism, creations of forty years of "new modelism", with its acquired insular modes of thought and associated petty craft jealousies, treated the hand of friendship with ultra-caution and suspicion.

The strike was a challenge to the strength and unity of the skilled unions' machine and, incidentally, to its relations with the general labour unions. All the unions failed the test and the consequencies of failure were harsh. As late as March 1898 an ASE official was trying to secure the reinstatement of engineers "still blacklisted" at the Barrow shipyard. The industrial and political unity of the Trades Council was, temporarily, retarded. The ASE's national membership fell to 83,500 in 1898 and, by 1900, it was still 4000 less than it had been in 1897 . For the industry as a whole the outcome of the dispute was one factor which kept British engineering free from serious national disruption until the First World War and the "management functions" lock-out of 1922. This is not the place to make a strictly economic assessment of the 1897-98 dispute. However, it may have been the case that the price of relative peace, paid in terms of scarred industrial social psychology and a legacy of bitterness, between the unions as well as between labour and management, was an astonishingly high price indeed.

another ASE member and later became a Labour Member of Parliament for Barrow-in-Furness (1906-18), formed the Workers' Union, in 1898, to overcome craft/labourer divisions by recruiting non-union engineering workers. Richard Hyman, The Workers' Union (Oxford, 1971), pp. 1-11, substantiates the connection between the engineering dispute and the formation of the new union. 